\title{
Effect of amount of milk fed, weaning age and starter protein level on growth performance in Holstein calves
}

\author{
Serkan Ozkaya and M. Turan Toker \\ Department of Animal Science, Faculty of Agriculture, Suleyman Demirel University, Isparta, Turkey
}

\begin{abstract}
The objectives of this study were to investigate the effects of amount of milk fed, weaning age and difference of starter protein levels on growth performance of female Holstein Friesian calves. Forty Holstein calves were housed in individual boxes. Calves were divided into 2 groups $(n=20)$; first group was fed with whole milk with the amount of $10 \%$ of their body weight (BW), while the second group was fed with whole milk with the amount of $8 \%$ of their BW. These 2 groups were divided into sub-groups of calves ( $n=10$ for each) again. One of the sub-groups was fed with whole milk for a period of 8 weeks, while the other group was fed with whole milk for a period of 5 weeks. Once again the sub-groups were divided into 2 groups ( $n=5$ for each). One of these groups was fed with starter diet containing $22 \%$ crude protein (CP), while the other group was fed with starter diet containing $18 \%$ CP ad libitum as the starting feed. After an 8-week period, Calves which were fed by the whole milk of $\% 10$ of their BW were defined to be heavier than those which were fed by $\% 8$ whole milk of their BW. The effect of weaning age and protein level of starter on BW was not statistically significant. The results showed that the body weight gains of the calves receiving milk at $10 \%$ of BW were better, early weaning tended to increase feed consumption and the protein levels did not affect the performance of calves.
\end{abstract}

Keywords: calves, amount of milk fed, weaning age, starter protein level, Holstein, body weight, body measurements

\section{Introduction}

Female calves are generally raised to replace cow leaving herd because of aging, yield loss, beginning of mastitis and further health reasons. Therefore, maintenance and feeding of calves is important for future of dairy farming.

The NRC (2001) and USDA (2002) recommended $18 \%$ crude protein (CP) in calf starters and an average weaning age of 8.4 weeks, respectively. Schingoethe et al. (2001) and AmaralPhillips (2009) reported that calves should be fed with whole milk or milk replacer at 8 to $10 \%$ of their birth weight. This amount can be fed in one or two meals a day.

Several studies showed that there are no differences in body weight (BW) between weaning ages (Hill et al. 2005, Koçak \& Guneş 2005, Kehoe et al. 2007). Khan et al. (2007a, b) and Kehoe et al. (2007) indicated that the feed intake of the early weaned calves was higher than the conventionally weaned calves. However Koçak \& Guneş (2005) and Quigley et al. (2006) determined that there were no significant differences between early weaned and late weaned calves. 
Hill et al. (2005) indicated that there were no differences in the performance of calves' feed 18 and $22 \%$ starters. However, Drackley et al. (2002) found that calves fed with starters containing $22 \%$ CP were more efficient than those fed $18 \%$ CP. Sekine et al. (2004) and Labussiere et al. (2008) showed that performance and feed intake of calves was not affected by CP concentration of the starters.

Isik \& Toker (1980) found that the amount of consumed milk did not affect the BW. Koçak \& Guneş (2005), Kristensen et al. (2007), Tapkı (2007) and Kehoe et al. (2007) declared that there were no significant effects of the amount of consumed milk on BW but significant effects on feed intake of calves. However, Fiems et al. (2005), Terré et al. (2006) and Khan et al. (2007a, b) found that milk fed level of calves were significant on BW. Moreover, Khan et al. (2007b) indicated that the feed intake of calves was significant.

The use of consumed milk amount, weaning age and starter protein level were evaluated separately on calves' performance by some of the researchers, while some of them studied and evaluated under the titles of »The weaning age and starter protein«, »Feeding with received milk and weaning age «. Therefore, the objective of the present study is to determine the effects of amount of received milk feed, weaning age and starter protein level on growth performance of female Holstein calves.

\section{Material and methods}

All the experimental procedures were reviewed and approved by the Animal Tests Local Ethical Council of Suleyman Demirel University, Turkey.

\section{Animal, housing and diet}

An average of 7.5-day old 40 female Holstein calves were used as research material and samples were obtained from Isparta, Burdur, Aydin, Izmir and nearby provinces of Turkey. Prior to the transportation, calves were injected with $5 \mathrm{~cm}^{3}$ of Vitamin $C$ and $3 \mathrm{~cm}^{3}$ antibiotics and in order to prevent dehydration, a liquid consisted of sugar and salt is also provided. After the transportation, calves were injected $3 \mathrm{~cm}^{3}$ antibiotics to prevent infection and were weighed and moved into individual pens $(1.0 \times 1.5 \mathrm{~m})$. Calves were kept in individual pens until 1 week after the weaning. Calves were divided into two groups $(n=20)$ randomly; while the first group were fed with the received milk with the amount of $10 \%$ of their live weight, and the second group were fed with the received milk with the amount of $8 \%$ of their live weight. These two groups were divided into sub-groups of calves ( $n=10$ for each) again. One of the sub-groups was fed with received milk for an 8-week period, while the other groups were fed with received milk for a 5-week period. These sub-groups among themselves were divided into two sub-groups again ( $\mathrm{n}=5$ for each) and one of these was fed with starter diet containing $22 \%$ CP while the second group received feed containing $18 \% \mathrm{CP}$ as the starter. Calves were fed by whole milk daily at 07:00 and 18:00. Calves were offered water as a free choice daily. 


\section{Feed nutrient composition}

Composition of calf starter, alfalfa hay, whole milk, extraction soybean meal used throughout the study is presented in Table 1.

Dry matter and ash content in milk was determined by the gravimetric method, fat was obtained by the Gerber method and protein content of milk was determined by the Kjeldahl method (Kirdar 2001). The Kjeldahl method was used to determine protein, and ether extract was determined using the Soxhlet method in starters (AOAC 1990). Acid and Neutral detergent fibre were analysed by the ANKOM220 Fibre Analyzer (Ankom Technology, Macedon, NY, USA). Metabolic energy value was calculated according to the TSE (1991) values.

Table 1

Composition of milk, calf starters, alfalfa hay and extraction soybean meal used throughout the study

\begin{tabular}{lccccc}
\hline Item & Milk & Starter (1) & Starter (2) & Alfalfa hay & $\begin{array}{c}\text { Extracted } \\
\text { soybean meal }\end{array}$ \\
\hline Dry matter, \% & 11.02 & 90.22 & 91.44 & 93.39 & 90.07 \\
Organic matter, \% & 7.56 & 83.62 & 84.87 & 83.47 & 83.58 \\
Crude protein, \% & 3.27 & 18.25 & 21.93 & 15.06 & 48.43 \\
Ether extract, \% & 3.30 & 4.40 & 3.35 & 2.06 & 1.05 \\
Lactose & 4.10 & & & & \\
Crude fibre, \% & - & 8.20 & 8.25 & 30.49 & 4.50 \\
Nitrogen free extract*, \% & - & 52.77 & 51.34 & 35.86 & 29.60 \\
Acid detergent fibre, \% & - & - & - & 29.08 & - \\
Neutral detergent fibre, \% & - & - & - & 40.19 & - \\
Ash, \% & 0.35 & 6.60 & 6.57 & 9.92 & 6.49 \\
ME, kcal/kg & - & 2632 & 2651 & 1631 & 2800 \\
\hline
\end{tabular}

Faecal scoring and experimental measurements

Scour score was recorded daily according to Kaya et al. (2000) as follows: 1 - normal (soft solid consistency, no fluid), 2 - soft (semisolid, mostly solid), 3 - runny (semisolid, mostly solid) and 4 - watery (fluid). When diarrhoea cases were seen, oral electrolyte was provided (Baymix, Bayer AG, Leverkusen, Germany) and it was performed as following: $100 \mathrm{~g}$ of oral electrolyte diluted in $2.0 \mathrm{~kg}$ of water for each feeding. Body temperatures were recorded daily for each calf for the end of study. Temperature $>39.8^{\circ} \mathrm{C}$ were considered to be high fever and calves were injected with antibiotics and antipyretics. BW of calves was measured weekly by using a digital weighing scale before feeding with received milk. Body measurements including body length, wither height, chest depth, chest girth, hip width and height were measured weekly using measuring stick and tape (Hauptner \& Herberholz GmbH \& Co. KG, Solingen, Germany), when calves were standing as described in Ozkaya \& Bozkurt (2008). Starter and alfalfa hay intake was recorded weekly. Starter, alfalfa hay and water were picked up in front of calves at night before weighing and thus calves were weighed before feeding.

\section{Statistical analysis}

The results were assessed by repeated measurements analysis of variance using SPSS 16 (SPSS Inc., Chicago, IL, USA), initial body measurements (body weight [BW], body length [BL], 
wither height [WH], body depth [BD], hip height [HH], hip width [HW], chest girth [CG]) were used as a covariate, and the Tukey test was conducted to determine the differences between group means. The statistical model for analysis was given as:

$$
\begin{aligned}
& y_{i j k m l}=\mu+X_{i j k m}+a_{i}+\beta_{j}+Y_{k}+\alpha \beta_{i j}+a \gamma_{i k}+\beta Y_{j k}+\alpha \beta Y_{i j k}+\pi_{l(j i k)}+Y_{m}+a Y_{i m}+\beta Y_{j m}+\gamma Y_{k m}+a \beta Y_{i j m} \\
& +\alpha \gamma Y_{i k m}+\beta \gamma Y_{j k m}+\alpha \beta Y Y_{i j k m}+Y \mu_{m(j i k)}+\varepsilon_{n(j k m l)}
\end{aligned}
$$

where $y_{i j k m /}$ is the dependent variable, $\mu$ is the overall mean, $X_{i j k m}$ is the measured value of covariate, $a_{i}$ is the effect of milk fed factor $i, \beta_{j}$ is the Effect of weaning age factor $j, \gamma_{k}$ is the effect of protein level of starter $k, \alpha \beta_{i j}$ is the effect of interaction between milk fed and weaning age, $a \gamma_{i k}$ is the effect of interaction between milk fed and protein level of starter, $\beta \gamma_{j k}$ is the effect of interaction between weaning age and protein level of starter, $\alpha \beta \gamma_{i j k}$ is the effect of interaction among milk fed, weaning age and protein level of starter, $\pi_{(i j k)}$ is the error $1, Y_{m}$ is the effect of week factor $m, a Y_{i m}$ is the effect of interaction between milk fed and week, $\beta Y_{j m}$ is the effect of interaction between weaning age and week, is the effect of interaction between protein level of starter and week, $\gamma Y_{k m}$ is the effect of interaction among milk fed, weaning age and week, $a \beta Y_{i j m}$ is the effect of interaction among milk fed, protein level of starter and week, $a \gamma Y_{i k m}$ is the effect of interaction among of weaning age, protein level of starter and week, $a \beta \gamma Y_{i j k m}$ is the effect of interaction among milk fed, weaning age, protein level of starter and week and $Y_{m((j) k)}+\varepsilon_{n(j i k m) !}$ is the error 2 .

There are two levels of milk fed factor ( $8 \%$ and $10 \%$ of their BW), two levels of weaning age factor ( 8 and 5 week's age), two levels of protein level of starter factor (18\% and $22 \% \mathrm{CP}$ ) and eight levels of week factor (1st, 2nd, 3rd, 4th, 5th, 6th, 7th, 8th week). Following the total experiments and the levels of the weeks, repeated measurements were applied.

To minimise the seasonal effects, calves which were brought to the farm in the same period were distributed into the groups according to the order of arrival.

\section{Results and discussion}

\section{Body weight}

Average daily weight gain was higher in milk fed $10 \% \mathrm{BW}$ than received milk fed $8 \% \mathrm{BW}$ at the 8-week age (Table 2 ) and it was statistically significant $(P<0.05)$. Reducing the amount of received milk fed was caused the slowdown of calves' weight gain. One of the major reasons was that the calves were receiving enough nutrients due to the reduced amount of milk fed (Appleby et al. 2001). Weight gain of calves could have been affected depending on the consumption of larger amounts of milk which also increases the digestion capacity and absorbing more nutrients in milk and these effects the growth of calves (Blum \& Baumrucker 2002). Results in study showed similar with Steinhardt et al. (2005), Quigley et al. (2006), Terré et al. (2006) and Khan et al. (2007a, 2007b) which are reported that depending on consuming larger amount of milk fed concluded in higher weight gain.

There were no significant differences between weaning age ( 5 and 8 weeks old) and protein level of starter (18 and $22 \%$ CP) on BW (Table 2). Early weaned calves encountered some difficulties adapting to the starter feed and lower feed efficiency could have showed differences between weights which were weaned 5 and 8 weeks of age (Winter 1978). These results were similar to those of Ugur et al. (1999), Hill et al. (2005), Koçak \& Guneş (2005) and 


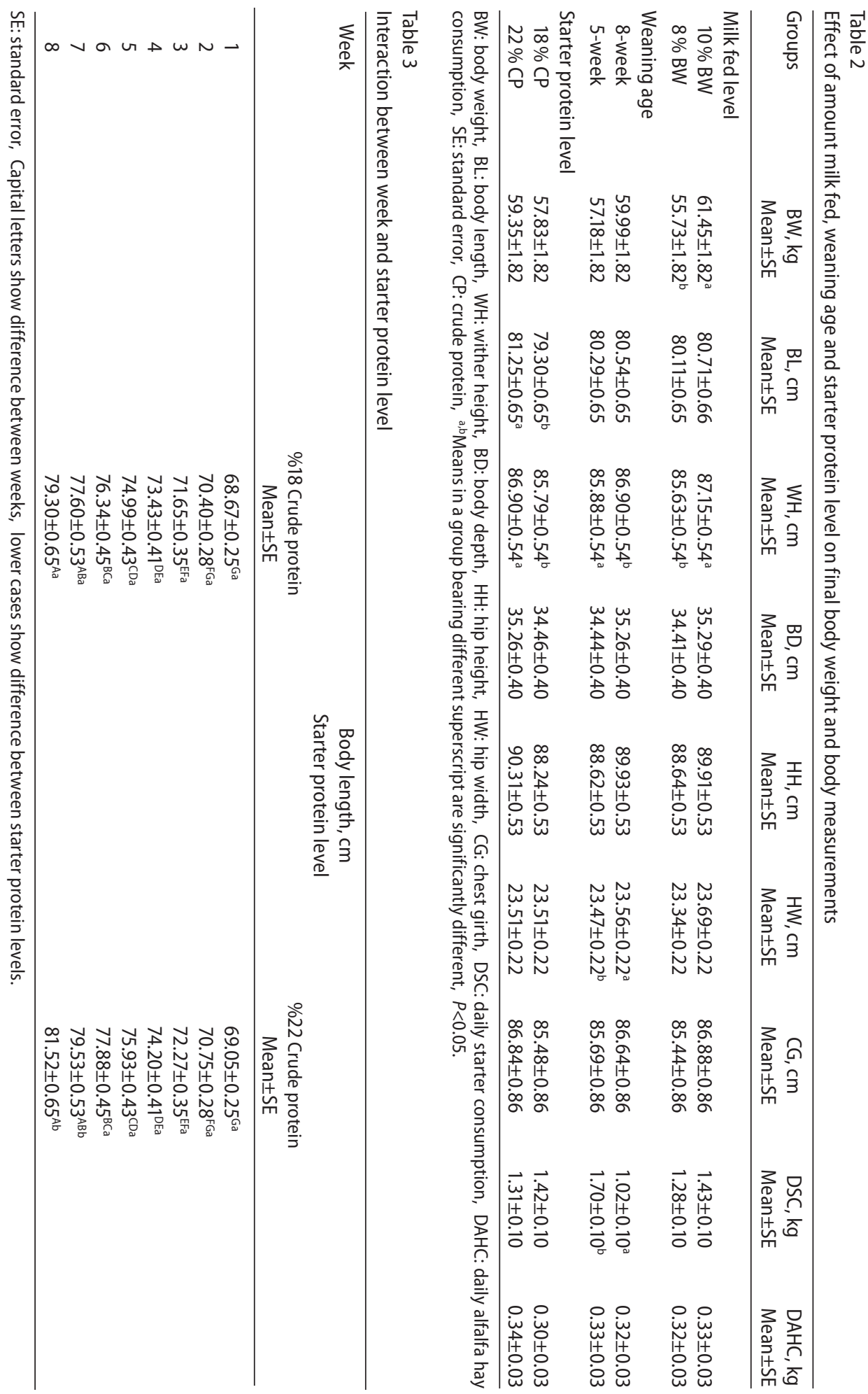


Kehoe et al. (2007). Akayezu et al. (1994) as indicated that calves' body weight increased depending on the increase of starter protein level, maximum growth was obtained with the amount of $19.6 \%$ CP, but there were no advantage of $22.4 \%$ CP level. Therefore, although statistically there is no difference, the reason of lower performance of calves with fed $18 \% \mathrm{CP}$ level starter were fed lower than optimal protein level. The similar results were also observed in Drackley et al. (2002), Hill et al. (2005) and Labussiere et al. (2008) studies.

\section{Body measurements}

Analyses of variance for each parameter (BL, BD, WH, $\mathrm{HH}, \mathrm{HW}$ and $\mathrm{CG}$ ) are shown in Table 2. Although the numerical differences were found between amount of milk fed on body measurements (without WH), these differences were not significant $(P>0.05)$. This is in agreement with other researcher who reported no significant growth among calves (Tapkı 2007). Other researcher reported that the calves were longer and higher in excess milk fed than small amount of milk fed (Khan et al. 2007a, 2007b). Amount of milk fed was significant for WH. This result was found similar to Khan et al. (2007a, 2007b). However, Tapkı (2007) reported that there were no differences for WH of calves between amounts of milk fed.

Also there were no significant differences for BL, BD, HH and CG for weaning age (Table 2). This result was similar to Kehoe et al. (2007). However, another research reported that early weaned calves were shorter than late weaned ones (Khan et al. 2007a, 2007b). Weaning age was statistically significant for WH and HW. This result was similar to Khan et al. (2007a, 2007b) but that result was not compatible with Hill et al. (2005) and Kehoe et al. (2007).

Starter protein level was significant for BL and WH (Table 2). However, there was no significance during the first 6 weeks; differences began between 18 to $22 \%$ CP level at 7 and 8 weeks (Table 3). Hill et al. (2005) and Akayezu et al. (1994) reported that starter protein level did not affect the $\mathrm{BL}$ and $\mathrm{WH}$.

There were significant $(P<0.05)$ interactions between week and amounts of milk fed (Table 4) and also among week, weaning age and starter protein level (Table 5) on WH. There were no significant interaction during the first 6 weeks but significance begins in the 7th and 8th week.

Table 4

Interaction between week and amount of milk fed

\begin{tabular}{lcc}
\hline Week & $\begin{array}{c}\text { Wither height, } \mathrm{cm} \\
\text { Mean } \pm \text { SE }\end{array}$ & $\begin{array}{c}8 \% \text { Body weight } \\
\text { Mean } \pm \text { SE }\end{array}$ \\
\hline 1 & $76.62 \pm 0.24^{\mathrm{Ga}}$ & $76.30 \pm 0.24^{\mathrm{Ga}}$ \\
2 & $78.32 \pm 0.38^{\mathrm{Fa}}$ & $77.93 \pm 0.38^{\mathrm{Fa}}$ \\
3 & $79.95 \pm 0.42^{\mathrm{Ea}}$ & $79.50 \pm 0.42^{\mathrm{Ea}}$ \\
4 & $81.47 \pm 0.44^{\mathrm{DEa}}$ & $80.90 \pm 0.44^{\mathrm{DEa}}$ \\
5 & $82.85 \pm 0.45^{\mathrm{CDa}}$ & $82.10 \pm 0.45^{\mathrm{CDa}}$ \\
6 & $84.31 \pm 0.50^{\mathrm{BCa}}$ & $83.19 \pm 0.50^{\mathrm{BCa}}$ \\
7 & $85.83 \pm 0.55^{\mathrm{ABa}}$ & $84.25 \pm 0.55^{\mathrm{ABb}}$ \\
8 & $87.83 \pm 0.54^{\text {Aa }}$ & $85.63 \pm 0.54^{\mathrm{Ab}}$ \\
\hline
\end{tabular}

SE: standard error, Capital letters show difference between weeks, lower cases show difference between amounts of milk fed. 
Table 5 showed that there were significant interaction among the week, weaning age and starter protein level for 7 and 8 weeks $(P<0.05)$ and it was also significant among 6,7 and 8 weeks on weaning age and starter protein level ( $22 \% \mathrm{CP})$.

Table 5

Interaction between week, weaning age and starter protein level

\begin{tabular}{|c|c|c|c|}
\hline \multirow[t]{2}{*}{ Starter protein level } & \multirow[t]{2}{*}{ Week } & \multicolumn{2}{|c|}{$\begin{array}{l}\text { Wither height, } \mathrm{cm} \\
\text { Mean } \pm \mathrm{SE}\end{array}$} \\
\hline & & 8 weeks & 5 weeks \\
\hline \multirow[t]{8}{*}{$18 \%$ Crude protein } & 1 & $76.35 \pm 0.34^{\text {Gaa }}$ & $76.50 \pm 0.34^{\text {Da } a}$ \\
\hline & 2 & $78.02 \pm 0.54^{\mathrm{FGaa}}$ & $78.04 \pm 0.54^{\mathrm{FGa} a}$ \\
\hline & 3 & $79.36 \pm 0.60^{\text {ЕFаa }}$ & $79.80 \pm 0.59^{\text {ЕFа } a}$ \\
\hline & 4 & $80.45 \pm 0.63^{\text {DЕа } a}$ & $81.05 \pm 0.62^{\text {DEa } a}$ \\
\hline & 5 & $81.71 \pm 0.65^{\mathrm{CDa} a}$ & $82.15 \pm 0.64^{\mathrm{CDa} a}$ \\
\hline & 6 & $82.72 \pm 0.70^{\mathrm{BCa} a}$ & $83.64 \pm 0.70^{\text {ВСа } а}$ \\
\hline & 7 & $84.04 \pm 0.78^{\mathrm{ABa} a}$ & $84.78 \pm 0.78^{\mathrm{ABa} a}$ \\
\hline & 8 & $85.39 \pm 0.77^{\text {Аа } a}$ & $86.18 \pm 0.76^{\text {Ааa }}$ \\
\hline \multirow[t]{8}{*}{$22 \%$ Crude protein } & 1 & $76.70 \pm 0.34^{\mathrm{Gaa}}$ & $76.30 \pm 0.34^{\mathrm{Ga} a}$ \\
\hline & 2 & $78.43 \pm 0.54^{\mathrm{FGa} a}$ & $78.01 \pm 0.54^{\mathrm{FGa} a}$ \\
\hline & 3 & $80.54 \pm 0.59^{\text {ЕҒа } a}$ & $79.20 \pm 0.59^{\text {ЕҒа } a}$ \\
\hline & 4 & $82.30 \pm 0.63^{\text {DЕа } a}$ & $80.95 \pm 0.62^{\text {DEa } a}$ \\
\hline & 5 & $83.79 \pm 0.65^{\mathrm{CDa} a}$ & $82.25 \pm 0.64^{\mathrm{CDa} a}$ \\
\hline & 6 & $85.48 \pm 0.71^{\mathrm{BCa} a}$ & $83.16 \pm 0.70^{\mathrm{BCa} b}$ \\
\hline & 7 & $86.86 \pm 0.78^{\mathrm{ABb} a}$ & $84.47 \pm 0.78^{\mathrm{ABab}}$ \\
\hline & 8 & $88.40 \pm 0.77^{\mathrm{Aba}}$ & $85.57 \pm 0.76^{\text {Aab }}$ \\
\hline
\end{tabular}

SE: standard error, Capital letters show difference between weeks, lower cases show difference between starter protein levels and italic letters show difference between weaning ages.

The significant interaction between weaning age and starter protein levels was found on HW (Table 6).

Table 6

Interaction between weaning ages and starter protein levels on hip width

\begin{tabular}{llc}
\hline Weaning age & Starter protein level & $\begin{array}{c}\text { Hip width, } \mathrm{cm} \\
\text { Mean } \pm \mathrm{SE}\end{array}$ \\
\hline 8 weeks & $18 \%$ Crude protein & $21.37 \pm 0.20^{\mathrm{Ab}}$ \\
& $22 \%$ Crude protein & $21.83 \pm 0.20^{\mathrm{Ba}}$ \\
& $18 \%$ Crude protein & $21.84 \pm 0.21^{\mathrm{Ba}}$ \\
& $22 \%$ Crude protein & $21.37 \pm 0.21^{\mathrm{Ab}}$ \\
\hline
\end{tabular}

SE: standard error, Capital letters show difference between weaning ages, lower cases show difference between starter protein levels

\section{Feed intake}

Means of daily starter consumption of calves are presented in Table 2. There were no significant differences in amounts of milk fed of calves on daily starter consumption. Feeding calves milk at $10 \%$ of their BW was begun to early consumption of starter (average 10.8 days) and consequently, because it provided early rumen development of calves, over 
consumption of starter occurred (Blum \& Baumrucker 2002). The other reason for it, the starter feed consumption increased depending on the increasing BW of calves (Koknaroglu et al. 2006, 2008 and NRC 1996).

Table 2 showed that there were significant differences between weaning ages for daily starter consumption $(P<0.05)$. Early weaned calves showed more tendencies on starter consumption. The reason for that, the early weaned calves may provide energy and protein requirements from starter. The results in this study were similar to Quigley et al. (2006) and Khan et al. (2007b).

There was no significance between starter protein levels for daily starter consumption (Table 2). Similar results were obtained with Drackley et al. (2002), Hill et al. (2005) and Labussiere et al. (2008) who have concluded that there are no effects of starter protein level on daily starter consumption.

Interaction between week and weaning age were found significant (Table 7). The factor of weaning age was significant $(P<0.05)$ on daily starter consumption for the 6 th, 7 th and 8th week. Starter consumption of early weaned calves increased rapidly after weaning. This result supports Luchini et al. (1991).

Table 7

Interaction between week and weaning age on daily starter consumption

\begin{tabular}{llc}
\hline Week & $\begin{array}{c}\text { Daily starter consumption, kg } \\
\text { Mean } \pm \text { SE }\end{array}$ & $\begin{array}{c}5 \text { weeks } \\
\text { Mean } \pm \text { SE }\end{array}$ \\
\hline 1 & $0.06 \pm 0.01^{\mathrm{Fa}}$ & $0.06 \pm 0.01^{\mathrm{Da}}$ \\
2 & $0.17 \pm 0.02^{\mathrm{EFa}}$ & $0.13 \pm 0.02^{\mathrm{Da}}$ \\
3 & $0.29 \pm 0.03^{\mathrm{DEFa}}$ & $0.24 \pm 0.03^{\mathrm{CDa}}$ \\
4 & $0.46 \pm 0.05^{\mathrm{CDEa}}$ & $0.39 \pm 0.05^{\mathrm{CDa}}$ \\
5 & $0.60 \pm 0.05^{\mathrm{BCDa}}$ & $0.56 \pm 0.05^{\mathrm{Ca}}$ \\
6 & $0.75 \pm 0.07^{\mathrm{ABCa}}$ & $1.06 \pm 0.07^{\mathrm{Bb}}$ \\
7 & $0.86 \pm 0.08^{\mathrm{ABa}}$ & $1.41 \pm 0.08^{\mathrm{Ab}}$ \\
8 & $1.02 \pm 0.10^{\mathrm{Aa}}$ & $1.70 \pm 0.10^{\mathrm{Ab}}$ \\
\hline
\end{tabular}

SE: standard error, Capital letters show difference between weeks, lower cases show difference between weaning ages.

Means for daily alfalfa hay consumption are presented in Table 2. There were no significant differences for the amount of milk fed, weaning age and starter protein level on daily alfalfa hay consumption. Tapkı (2007) reported that the amount of milk fed of calves were significant on daily alfalfa hay consumption. The consumption of alfalfa hay slightly increased in early weaned calves. This result was similar to Quigley et al. (1991).

Interaction among the amount of milk fed, weaning age and starter protein level on BW and body measurements at 8 weeks of age are presented in Table 8 . The interaction did not show any significance. The best performance has been obtained from calves, which were fed with milk $10 \%$ BW and weaned 8 weeks of age; also consuming starter contained $22 \%$ CP. The lowest cost in terms of total cost has been obtained when fed wit milk $8 \% \mathrm{BW}$ and weaned 5 weeks of age and also consumed starter contained $22 \%$ CP. 
Table 8

Interaction among amount of milk fed, weaning age and starter protein level on body weight and body measurements at 8 weeks of age

\begin{tabular}{|c|c|c|c|c|c|c|c|c|}
\hline & \multicolumn{4}{|c|}{$10 \%$ Body weight } & \multicolumn{4}{|c|}{$8 \%$ Body weight } \\
\hline & \multicolumn{2}{|c|}{8 weeks } & \multicolumn{2}{|c|}{5 weeks } & \multicolumn{2}{|c|}{8 weeks } & \multicolumn{2}{|c|}{5 weeks } \\
\hline & $\begin{array}{c}18 \% \text { CP } \\
\text { Mean } \pm \text { SE }\end{array}$ & $\begin{array}{r}22 \% \mathrm{CP} \\
\text { Mean } \pm \text { SE }\end{array}$ & $\begin{array}{c}18 \% \text { CP } \\
\text { Mean } \pm \text { SE }\end{array}$ & $\begin{array}{c}22 \% \text { CP } \\
\text { Mean } \pm \text { SE }\end{array}$ & $\begin{array}{c}18 \% \mathrm{CP} \\
\text { Mean } \pm \mathrm{SE}\end{array}$ & $\begin{array}{r}22 \% \mathrm{CP} \\
\text { Mean } \pm \text { SE }\end{array}$ & $\begin{array}{c}18 \% \text { CP } \\
\text { Mean } \pm \text { SE }\end{array}$ & $\begin{array}{r}22 \% \mathrm{CP} \\
\text { Mean } \pm \text { SE }\end{array}$ \\
\hline $\mathrm{W}, \mathrm{kg}$ & $63.53 \pm 3.63$ & $64.62 \pm 3.63$ & $60.96 \pm 3.64$ & $56.64 \pm 3.64$ & $51.32 \pm 3.64$ & $60.46 \pm 3.63$ & $55.46 \pm 3.63$ & $55.67 \pm 3.64$ \\
\hline $\mathrm{BL}, \mathrm{cm}$ & $78.72 \pm 1.32$ & $82.90 \pm 1.30$ & $80.86 \pm 1.32$ & 80.38 & $79.15=$ & $81.39 \pm$ & $78.48 \pm 1.30$ & $81.42 \pm 1.30$ \\
\hline $\mathrm{WH}, \mathrm{cm}$ & $87.08 \pm 1.08$ & $88.43 \pm 1.09$ & $87.22 \pm 1.08$ & $85.87 \pm$ & $83.71 \pm 1.08$ & $88.38 \pm 1.08$ & $85.14 \pm 1.08$ & $85.27 \pm 1.09$ \\
\hline $\mathrm{BD}, \mathrm{cm}$ & $35.14 \pm 0.81$ & $36.08 \pm 0.80$ & $35.49 \pm 0.81$ & $34.47 \pm 0.80$ & $33.76 \pm 0.80$ & $36.07 \pm 0.80$ & $33.35 \pm 0.80$ & $34.45 \pm 0.80$ \\
\hline $\mathrm{HH}, \mathrm{cm}$ & $89.95 \pm 1.06$ & $91.02 \pm 1.06$ & $89.19 \pm 1.06$ & $89.50 \pm 1.06$ & $86.76 \pm 1.06$ & $92.01 \pm 1.06$ & $87.06 \pm 1.06$ & $88.72 \pm 1.06$ \\
\hline $\mathrm{HW}, \mathrm{cm}$ & $23.40 \pm 0.43$ & $24.04 \pm 0.43$ & $24.22 \pm 0.44$ & $23.09 \pm 0.43$ & $23.07 \pm 0.43$ & $23.73 \pm 0.43$ & $23.36 \pm 0.43$ & $23.20 \pm 0.43$ \\
\hline $\mathrm{CG}, \mathrm{cm}$ & $87.03 \pm 1.75$ & $88.14 \pm 1.71$ & $86.89 \pm 1.71$ & $85.47 \pm 1.71$ & $82.60 \pm 1.71$ & $88.79 \pm 1.71$ & $85.40 \pm 1.72$ & $84.97 \pm 1.71$ \\
\hline DSC, kg & $1.25 \pm 0.24$ & $1.07 \pm 0.24$ & $1.97 \pm 0.24$ & $1.41 \pm 0.24$ & $0.66 \pm 0.24$ & $1.09 \pm 0.24$ & $1.71 \pm 0.24$ & $1.70 \pm 0.19$ \\
\hline DAHC, $\mathrm{kg}$ & $0.28 \pm 0.06$ & $0.38 \pm 0.06$ & $0.30 \pm 0.06$ & $0.35 \pm 0.06$ & $0.32 \pm 0.06$ & $0.28 \pm 0.06$ & $0.31 \pm 0.06$ & $0.37 \pm 0.06$ \\
\hline SS & 1.5 & 1.4 & 1.4 & 1.4 & 1.4 & 1.4 & 1.4 & 1.6 \\
\hline $\mathrm{BT},{ }^{\circ} \mathrm{C}$ & 38.9 & 38.9 & 38.9 & 39.1 & 39.2 & 39.0 & 39.0 & 39.0 \\
\hline Cost & $354.56 \$$ & $341.34 \$$ & $283.70 \$$ & $300.75 \$$ & $260.87 \$$ & $305.63 \$$ & $238.36 \$$ & $260.17 \$$ \\
\hline
\end{tabular}

BW: body weight, BL: body length, WH: wither height, BD: body depth, HH: hip height, HW: hip width, CG: chest girth, DSC: daily starter consumption, DAHC: daily alfalfa hay consumption, SS: scour score, BT: Body temperature, CP: crude protein, SE: standard error

\section{Health}

During the study, there were no significant differences which have been observed between scour and body temperatures of calves (Table 8). Hammon et al. (2002) reported that there is no relationship between amount of milk fed and diarrhoea, but diarrhoea is caused related to maintenance, housing and hygiene, and this result was supported by Hammon et al. (2002). Steinhardt \& Thielschen (2000) indicated that there was no statistical difference between the average body temperatures of calves.

In conclusion, rearing of calves to 8 weeks of age with whole milk $10 \%$ of their BW and starter containing $22 \%$ CP yielded better results compared to other composition of feeding. Farmers should use early weaning program which is milk fed $8 \%$ BW to 5 weeks of age and starter is contained $18 \%$ CP with good feeding and management conditions, when the milk costs are increased in Turkey.

\section{Acknowledgement}

This project was funded by Suleyman Demirel University Research Council (Project No: 1717D-08) as a doctoral thesis.

\section{References}

Akayezu JM, Linn JG, Otterby DE, Hansen WP (1994) Evaluation of calf starters containing different amounts of crude protein for growth of Holstein calves. J Dairy Sci 77, 1882-1889

Amaral-Phillips DM (2009) Nutrition of dairy heifers post-weaning for optimum economical growth. http:// www.uky.edu/Ag/AnimalSciences/dairy/extention/nut00031.pdf [last accessed 12.04.2012] 
AOAC (1990) Offical methods of analysis of the association of official analytical chemists. 14th ed., William Byrd Press Inc., Arlington, VA, USA

Appleby MC, Weary DM, Chua B (2001) Performance and feeding behaviour of calves on ad libitum milk from articial teats. Appl Anim Behav Sci 74, 191-201

Blum JW, Baumrucker CR (2002) Colostral and milk insulin-like growth factors and related substances: Mammary gland and neonatal (intestinal and systemic) targets. Domest Anim Endocrinol 23, 101-110

Drackley JK, Bartlett KS, Blome RM (2002) Protein content of milk replacers and calf starters for replacement calves. www.livestocktrail.uiuc.edu/dairynet/paperDisplay.cfm?ContentID=339 [last accessed 12.04.2012]

Fiems LO, van Caelenbergh W, de Campeneere S, de Brabander DL (2005) The influence of dietary energy level in double-muscled Belgian Blue cows during the indoor period on calf birth weight and development. Arch Tierz 48, Special Issue, 41-47

Hammon HM, Schiessler G, Nussbaum A, Blum JW (2002) Feed intake patterns, growth performance, and metabolic and endocrine traits in calves fed unlimited amounts of colostrum and milk by automate, starting in the neonatal period. J Dairy Sci 85, 3352-3362

Hill TM, Aldrich JM, Schlotterbeck RL (2005) Nutrient sources for solid feeds and factors affecting their intake by calves. In: Garnsworthy P (ed.) Calf and heifer rearing: principles of rearing the modern dairy heifer from calf to calving. Nottingham University Press, Nottingham, UK, 113-133

Isık N, Toker MT (1980) [Research on determining amount of full-fat milk feeding of Holstein calves]. FoodAgriculture and Affairs General Directorate of Ministry of Agriculture Publications, Isparta, Turkey [in Turkish]

Kaya A, Uzmay C, Alçiçek A, Kaya I (2000) [Research on rearing calves using acidified whole milk]. Turk J Anim Sci 24, 413-421 [in Turkish]

Kehoe SI, Dechow CD, Heinrichs AJ (2007) Effects of weaning age and milk feeding frequency on dairy calf growth, health and rumen parameters. Livest Sci 110, 267-272

Khan MA, Lee HJ, Lee WS, Kim HS, Kim SB, Ki KS, Ha JK, Lee HG, Choi YJ (2007a) Pre- and postweaning performance of Holstein female calves fed milk through step-down and conventional methods. J Dairy Sci $90,876-885$

Khan MA, Lee HJ, Lee WS, Kim HS, Ki KS, Hur TY, Suh GH, Kang SJ, Choi YJ (2007b) Structural growth, rumen development, and metabolic and immune responses of Holstein male calves fed milk through step-down and conventional methods. J Dairy Sci 90, 3376-3387

Kirdar SS (2001) [Milk and analysis methods of the industrial products practice guide]. S. D. U. Press, Isparta, Turkey [in Turkish]

Koknaroglu H, Toker MT, Bozkurt Y (2006) Effect of zeolite and initial weight on feedlot performance of Brown Swiss cattle. Asian J Anim Vet Adv 1, 49-54

Koknaroglu H, Loy DD, Hoffman MP (2008) Dry matter intake prediction of steers and heifers in the feedlot: Effect of initial weight on dry matter intake. Phillipp Agric Sci 91, 469-472

Koçak O, Guneş H (2005) The growth and survival characteristics of Holstein female calves weaned at various age. Turk J Vet Anim Sci 29, 511-516

Kristensen NB, Sehested J, Jensen SK, Vestergaard M (2007) Effect of milk allowance on concentrate intake, ruminal environment, and ruminal development in milk-fed Holstein calves. J Dairy Sci 90, 4346-4355

Labussiere E, Dubois S, van Milgen J, Bertrand G, Noblet J (2008) Effects of dietary crude protein on protein and fat deposition in milk-fed veal calves. J Dairy Sci 91, 4741-4754

Luchini ND, Lane SF, Combs DK (1991) Evaluation of starter diet crude protein level and feeding regimen for calves weaned at 26 days of age. J Dairy Sci 74, 3949-3955

NRC (1996) Nutrient Requirement of beef cattle. National Academies Press. Washington DC, USA

NRC (2001) Nutrient Requirement of dairy cattle. 7th rev. ed. National Academies Press, Washington, DC, USA

Ozkaya S, Bozkurt Y (2008) The relationship of parameters of body measures and body weight by using digital image analysis in pre-slaughter cattle. Arch Tierz 51, 120-128 
Quigley JD 3rd, Caldwell LA, Sinks GD, Heitmann RN (1991) Changes in blood glucose, nonesterified fatty acids, and ketones in reponse to weaning age and feed intake in young calves. J Dairy Sci 74, 250-257

Quigley JD, Wolfe TA, Elsasser TH (2006) Effects of additional milk replacer feeding on calf health, growth, and selected blood metabolites in calves. J Dairy Sci 89, 207-216

Schingoethe DJ (2001) Feeding and managing dairy calves and heifer. https://www.sdstate.edu/abe/wri/ water-quality/upload/EXEX4020.pdf [last accessed 12.04.2012]

Sekine J, Kamel HEM, Hisinuma M, Nasir A, Fadel El-Seed MA, Morita S, Hanada M, Kondo S (2004) Effect of protein sources with different rumen degradability in a diet on the efficiency of utilization of metabolizable energy by calves. Arch Tierz 47, 325-335

Steinhardt M, Thielscher HH (2000) [Growth and development quality of dairy calves reared in groups with an automatic milk feeder. Physiological variables and their changes at specific age periods]. Arch Tierz 43, 27-44 [in German]

Steinhardt M, Thielscher HH (2005) [Milk ingestion and growth performance of suckler calves (cross breeds Galloway $\times$ F1 Galloway $\times$ Holstein Friesian) from a cow-calf operation. Effect of sex and of life age calf and of the age of dam]. Arch Tierz 48, $12-23$ [in German]

Tapkı I (2007) Comparison of two conventional restricted daily milk allowance methods in dairy calf rearing with respect to growth and behavioural responses: 1. Growth responses. J Anim Vet Adv 6, 416-420

Terré M, Devant M, Bach A (2006) Performance and nitrogen metabolism of calves fed conventionally of fallowing an enhanced-growth feeding program during the preweaning period. Livest Sci 105, 109-119

TSE (1991) [Method of the determination metabolic (converted) energy of animal feeds]. Turkish Standards Institution. Standard No: 9610, Ankara, Turkey [in Turkish]

Uğur F, Yanar M, Tüzemen N (1999) Growth characteristics of early weaned Brown Swiss and Holstein Friesian cattle. J Agric Sci 5, 100-103

USDA (2002) Part I: References of dairy health and management in the United States, 2002. USDA: APHIS, National Animal Health Monitoring System, Fort Collins, CO, USA

Winter KA (1978) Response to weaning at two to five weeks of age by the young dairy calf. Can J Anim Sci 58, 377-383

Received 23 June 2011, accepted 10 January 2012.

Corresponding author:

Serkan Ozkaya

email: serkanozkaya@sdu.edu.tr or serkanozkaya31@gmail.com

Agricultural Research and Application Center, Suleyman Demirel University, 32260 Cunur-Isparta, Turkey 